\title{
Impact of the Cellular Prion Protein on Amyloid- $\beta$ and 3PO-Tau Processing
}

\author{
Matthias Schmitz ${ }^{\mathrm{a}, *}$, Katharina Wulf ${ }^{\mathrm{a}}$, Sandra C. Signore ${ }^{\mathrm{b}}$, Walter J. Schulz-Schaeffer ${ }^{\mathrm{c}}$, \\ Pawel Kermer ${ }^{\mathrm{b}}$, Mathias Bähr ${ }^{\mathrm{b}}$, Fred S. Wouters ${ }^{\mathrm{d}}$, Saima Zafar ${ }^{\mathrm{a}}$ and Inga Zerr ${ }^{\mathrm{a}}$ \\ ${ }^{a}$ Department of Neurology, Clinical Dementia Center and University Medical Center Göttingen, \\ Göttingen, Germany \\ ${ }^{\mathrm{b}}$ Department of Neurology, University Medical Center Göttingen, Göttingen, Germany \\ ${ }^{\mathrm{c}}$ Department of Neuropathology, University Medical Center Göttingen, Göttingen, Germany \\ ${ }^{\mathrm{d}}$ Laboratory for Molecular and Cellular Systems at the Institute for Neuro- \& Sensory Physiology, \\ Göttingen, Germany
}

Accepted 23 July 2013

\begin{abstract}
Previous studies indicate an important role for the cellular prion protein $\left(\mathrm{PrP}^{\mathrm{C}}\right)$ in the development of Alzheimer's disease $(\mathrm{AD})$ pathology. In the present study, we analyzed the involvement of $\mathrm{PrP}^{\mathrm{C}}$ in different pathological mechanisms underlying $\mathrm{AD}$ : the processing of the amyloid- $\beta$ protein precursor $(\mathrm{A} \beta \mathrm{PP})$ and its interaction with $\mathrm{A} \beta \mathrm{PP}$, tau, and different phosphorylated forms of the tau protein (p-tau). The effect of $\operatorname{PrP}^{\mathrm{C}}$ on tau expression was investigated in various cellular compartments using a HEK293 cell model expressing a tau mutant (3PO-tau) or wild type (WT)-tau.

We could show that $\mathrm{PrP}^{\mathrm{C}}$ reduces $\mathrm{A} \beta \mathrm{PP}$ cleavage, leading to decreased levels of $\mathrm{A} \beta_{40}$ and $\mathrm{sA} \beta \mathrm{PP}$ without changing the protein expression of $A \beta P P, \beta$-secretase, or $\gamma$-secretase. Tau and its phosphorylated forms were identified as interactions partners for $\mathrm{PrP}^{\mathrm{C}}$, raising the question as to whether $\operatorname{PrP}^{\mathrm{C}}$ might also be involved in tau pathology. Overexpression of $\operatorname{PrP}^{\mathrm{C}}$ in $P R N P$ and $3 \mathrm{PO}-$ tau transfected cells resulted in a reduction of 3PO-tau and p-tau as well as a decrease of 3PO-tau-related toxicity. In addition, we used the transgenic $\operatorname{PrP}^{\mathrm{C}}$ knockout (Prnp0/0) mouse line to study the dynamics of tau phosphorylation, an important pathological hallmark in the pathogenesis of $\mathrm{AD}$ in vivo. There, an effect of $\operatorname{PrP}^{\mathrm{C}}$ on tau expression could be observed under oxidative stress conditions but not during aging. In summary, we provide further evidence for interactions of $\operatorname{PrP}^{\mathrm{C}}$ with proteins that are known to be the key players in $\mathrm{AD}$ pathogenesis. We identified tau and its phosphorylated forms as potential PrP-interactors and report a novel protective function of $\operatorname{PrP}^{\mathrm{C}}$ in $\mathrm{AD}$-like tau pathology.
\end{abstract}

Keywords: Alzheimer's disease, amyloid, $\beta$-secretase, cellular prion protein, neuroprotection, 3PO-tau, p-tau

\section{INTRODUCTION}

The cellular prion protein $\left(\mathrm{PrP}^{\mathrm{C}}\right)$ is a highly conserved glycosylphosphatidylinositol (GPI)-anchored protein with a variety of functions such as copper binding, regulation of the circadian rhythm, and protection against oxidative stress [1-3].

Similar to tau and amyloid- $\beta$ protein precursor $(\mathrm{A} \beta \mathrm{PP}), \mathrm{PrP}^{\mathrm{C}}$ is localized in lipid rafts [4], which are

\footnotetext{
*Correspondence to: Matthias Schmitz, Department of Neurology, Clinical Dementia Center and University Medical Center Göttingen, Göttingen, Germany. Tel.: +49 5513910454; E-mail: matthias.schmitz@med.uni-goettingen.de.
}

strongly involved in signal transduction, e.g., through src kinases (Fyn/Erk1/2 activation) or receptor tyrosine kinases [5-7]. Previous studies indicated an association of $\mathrm{PrP}^{\mathrm{C}}$ with the cytoskeleton, where it modulates the expression of certain cytoskeletal proteins [8], and it may interact with tubulin [9-11]. Binding of $\operatorname{PrP}^{\mathrm{C}}$ to tubulin results in tubulin oligomerization and inhibition of microtubule formation [12]. Therefore, we now studied in detail its interaction with the tau protein, which is an important component of the microtubule cytoskeleton.

Besides its protective function under ischemic stress conditions [3, 13-15], evidence is accumulating that $\mathrm{PrP}^{\mathrm{C}}$ may play a role in Alzheimer's disease (AD) 
or during the development of AD-like pathology: 1) On a neuropathological level, $\operatorname{PrP}^{C}$ co-localizes with amyloid plaques [16, 17] which are present in Creutzfeldt-Jakob disease (CJD) patients with amyloid pathology [18]; 2) In humans, codon 129 polymorphism of the human $\operatorname{PrP}^{C}$ gene, resulting in either methionine or valine, influences the susceptibility to prion diseases. Furthermore, certain amino acid variations may also be a risk factor for early onset $\mathrm{AD}$ $[19,20]$ and the codon 129 polymorphism can modulate the number of amyloid deposits during cerebral aging [21]; 3) In disease models, the role of $\mathrm{PrP}^{\mathrm{C}}$ in the development of $\mathrm{AD}$-like pathology remains puzzling. Clear evidence exists that $\mathrm{PrP}^{\mathrm{C}}$ is involved in the pathophysiological metabolism of $\mathrm{A} \beta \mathrm{PP}$. $\operatorname{PrP}^{\mathrm{C}}$ contains an amyloid oligomer binding site, a region within the central part of $\mathrm{PrP}^{\mathrm{C}}$ from amino acid 95-110 [22]. $\mathrm{PrP}^{\mathrm{C}}$ thus may act as a potential receptor for amyloid- $\beta(A \beta)$ mediating the toxicity of $A \beta$ oligomers as shown in an AD mouse model $[23,24]$. A $\beta$ oligomers are thought to induce neuronal deficits in synaptic plasticity or neuronal cell death and the animals can be rescued when $\mathrm{PrP}^{\mathrm{C}}$ is knocked out [22] or by treatment with antibodies directed against $\operatorname{PrP}^{\mathrm{C}}$ [25]. Moreover, they can modulate the trafficking and expression of $\mathrm{PrP}^{\mathrm{C}}$ on the cell surface, a fact which lends further support to the hypothesis of a mutual interference between $A \beta$ and $\mathrm{PrP}^{\mathrm{C}}$ [26].

Nevertheless, three independent studies failed to confirm the postulated $\mathrm{PrP}^{\mathrm{C}}$-promoted toxic effects [27-29] leaving the debate on the role of $\operatorname{PrP}^{\mathrm{C}}$ still open.

In addition to amyloid plaques, the second major hallmark in $\mathrm{AD}$ is the formation of neurofibrillary tangles, consisting of hyperphosphorylated tau protein. Phosphorylation of tau protein at different sites is central to its pathologic effect, and its regulation occurs independently by different kinases. Therefore, we focused on different phosphorylated tau isoforms which are related to AD pathology. An interaction of $\operatorname{PrP}^{\mathrm{C}}$ and tau protein has already been demonstrated [30], suggesting a novel function of $\operatorname{PrP}^{\mathrm{C}}$ in the metabolism of tau under physiological and/or AD conditions. Whether this interaction results in a change in tau expression or phosphorylation remains unclear.

In the present study, we investigated the interaction of $\operatorname{PrP}^{\mathrm{C}}$ with $\mathrm{A} \beta \mathrm{PP}$, tau, p-tau Thr-181, and p-tau Ser396 and the impact of $\operatorname{PrP}^{\mathrm{C}}$ on the processing of A $\beta P P$. The effect of $\operatorname{PrP}^{\mathrm{C}}$ on tau-induced toxicity was analyzed in a human embryonic kidney 293 (HEK293) cell model co-expressing $\mathrm{PrP}^{\mathrm{C}}$ and a mutant form of tau (3PO-tau) that exhibits high toxicity, aggregation, and phosphorylation [31]. In Prnp0/O mice, we investigated the effects of aging and oxidative stress on the expression of tau and several isoforms of $\mathrm{p}$-tau in comparison to wild type (WT) mice.

\section{MATERIALS AND METHODS}

\section{Cell culture}

All chemicals were of analytical grade and obtained either from Sigma-Aldrich (Taufkirchen, Germany) or Merck (Darmstadt, Germany). HEK293 cells and SH-SY5Y, human neuroblastoma cells, were grown in Dulbecco's modified Eagle medium (DMEM, Sigma-Aldrich), supplemented with $10 \%$ fetal calf serum (Biochrom, Berlin, Germany), $1 \%$ penicillin/streptomycin, and 1\% L-glutamine (only for SH-SY5Y) (Biochrom) under standard culture conditions $\left(37^{\circ} \mathrm{C}, 5 \% \mathrm{CO}_{2}\right.$ supply, and $95 \%$ humidity). Both cell lines were split 1-2 times per week and the medium was exchanged at least every four days. The 293 cell line was derived by transformation of primary cultures of HEK cells with sheared adenovirus (Ad) 5 DNA. They behave similarly to neuronal cells [32].

\section{Cell survival}

Cell survival was assessed by crystal violet staining. Cells were fixed with $1 \%$ glutaraldehyde, washed with phosphate-buffered saline (PBS), and stained with crystal violet $(0.02 \%$ in water). The amount of crystal violet bound to the cells was dissolved with $70 \%$ ethanol. Data collection was performed with a spectrophotometer at a wavelength of $550 \mathrm{~nm}$.

\section{Transfection}

HEK293 and SH-SY5Y cells were transiently transfected with the pCMS-PRNP-EGFP vector, expressing human $\operatorname{PrP}^{\mathrm{C}}$ gene $(P R N P)$. An empty pCMS-EGFP vector was used as control. The generation of WTand 3PO-tau-GFP vectors was described in detail by Iliev et al. [31]. Plasmids were purified using the EndoFree Maxi Kit (Qiagen GmbH, Hilden, Germany). For the transfection, $1-1.5 \times 10^{6}$ cells were seeded in a six well plate for $24 \mathrm{~h}$. 1.5-2 $\mu \mathrm{g}$ of plasmid DNA and 4-6 $\mu$ l lipofectamine (Invitrogen, Groningen, Netherlands) were dissolved in $250 \mu$ l OptiMEM (Gibco/Invitrogen, Karlsruhe, Germany) for $5 \mathrm{~min}$. Stable DNA complexes were formed after 20-30 min and pipetted to the transfection medium (OptiMEM containing $2 \%$ FCS), in which the cells were incubated 
for $6-8 \mathrm{~h}$ or overnight. Thereafter, the transfection medium was replaced by fresh culture medium. After $48 \mathrm{~h}$, cells were washed in PBS and scraped on ice in cell-lysis buffer consisting of $50 \mathrm{mM}$ Tris-HCL $\mathrm{pH}$ $8.0,150 \mathrm{mM} \mathrm{NaCl}, 1 \%$ Triton X-100, and a proteaseand phosphatase inhibitor cocktail (Roche, Mannheim, Germany).

Transfected cells could be distinguished from non-transfected cells by the EGFP fluorescence (Supplementary Fig. 1). We quantified the transfections efficiencies. While $P R N P$ has a transfections efficiency of approximately $80 \%$, we observed an efficiency of $70 \%$ for $3 \mathrm{PO}$ tau. Consequently, we obtained more than $50 \%$ of double transfectants.

\section{Animals}

For each experiment, at least five adult male Prnp knockout mice (designated Prnp0/0) and WT mice aged between 3 and 15 months were used. The genetic background of both Prnp0/0 and WT mice was derived from both 129/Sv and C57BL/6 [33]. Prnp0/0 mice are homozygous for the disrupted $\mathrm{PrP}^{\mathrm{C}}$ gene (Zurich I), produced as previously described by Bueler et al. [33]. The transgenic mouse line 35 ( $\mathrm{Tg} 35)$ carries a cosmid transgene encoding the mouse PrP $\mathrm{b}$ allele which leads to an $8-10$ times overexpression of mouse $\mathrm{PrP}^{\mathrm{C}}$ in the brain.

Mice were housed, under controlled temperature conditions $\left(21-22^{\circ} \mathrm{C}\right)$, with free access to food and water in a $12: 12 \mathrm{~h}$ light:dark cycle. The body weight of all animals varied between 25 and $35 \mathrm{~g}$. All protocols used were in accordance with the ethical rules for animal experiments.

After mice were euthanized, brains were collected either whole or were dissociated on ice into three brain regions (hippocampus, cortex, and cerebellum). Subsequently, whole brains/brain regions were separated, complemented with lysis buffer containing $50 \mathrm{mM}$ Tris $\mathrm{HCl}(\mathrm{pH} 7.5), 150 \mathrm{mM} \mathrm{NaCl}, 2 \mathrm{mM}$ EDTA, $1 \%$ Triton $\mathrm{X}-100$, and protease/phosphatase inhibitor cocktail and homogenized. Brain lysate samples were incubated in a tube rotator (Schuett Labortechnik $\mathrm{GmbH}$, Goettingen, Germany) for $15 \mathrm{~min}$ and centrifuged at $4^{\circ} \mathrm{C}$ at $13000 \times \mathrm{g}$. Supernatants were transferred into separate tubes and stored at $-80^{\circ} \mathrm{C}$.

\section{Induction of transient focal cerebral ischemia}

Animals were anaesthetized with $1 \%-1.5 \%$ isoflurane $\left(30 \% \quad \mathrm{O}_{2}, 70 \% \quad \mathrm{~N}_{2} \mathrm{O}\right)$. Rectal temperature was maintained at $36.5-37^{\circ} \mathrm{C}$ using a feedback-controlled heating system. In order to assess cerebral blood flow, laser-Doppler flow was recorded during all experiments using a $0.5 \mathrm{~mm}$ fiberoptic probe (Perimed, Sweden) attached to the skull overlying the core region of the middle cerebral artery (MCA) territory ( $2 \mathrm{~mm}$ posterior, $6 \mathrm{~mm}$ lateral from bregma). Focal cerebral ischemia was induced by transient occlusion $(60 \mathrm{~min})$ of the MCA using the intraluminal filament technique. Following a midline neck incision, the left common and external carotid artery were isolated and ligated. After placing a microvascular clip (Aesculap, Germany) on the internal carotid artery, an 8-0 silicon resin (Xantopren, Deuker, Germany) coated nylon monofilament (Ethilon; diameter 180 to $200 \mu \mathrm{m}$; Ethicon, Germany) was introduced through an incision into the distal part of the common carotid artery and, after clip removal, advanced $9 \mathrm{~mm}$ distal from the carotid bifurcation for MCA occlusion. The monofilament was withdrawn after $60 \mathrm{~min}$ of ischemia to allow reperfusion of the MCA. Laser-Doppler flow recording continued for $15 \mathrm{~min}$ to monitor appropriate reperfusion.

\section{Immunohistochemical staining}

Cells or brain tissue were fixed in PBS containing $4 \%$ formaldehyde for $20 \mathrm{~min}$, washed 3 times with PBS and permeabilized by incubation in PBS containing $0.2 \%$ Triton $\mathrm{X}-100$ for $10 \mathrm{~min}$. Permeabilization was followed by $1 \mathrm{~h}$ blocking in PBS containing $2 \%$ bovine serum albumin (BSA). Subsequently, the specimens were incubated with primary antibody diluted $1: 500$ in PBS containing $1 \%$ BSA for $2 \mathrm{~h}$ at room temperature. All steps were carried out in a dark humidified chamber and were stopped by washing three times with PBS. Finally, stained material was mounted in Mowiol 4-88 (Roth, Karlsruhe, Germany) before examination of the staining under an Olympus BX51 microscope (Olympus, Hamburg, Germany) could be performed. Images were acquired and processed using cell F-software (Olympus).

\section{Immunoprecipitation analysis}

HEK293 cells were scraped on ice in PBS containing a cocktail of protease and phosphatase inhibitors and were sonicated. Afterwards, insoluble cell debris was removed by centrifugation at $5400 \times g$ for $15 \mathrm{~min}$ at $4{ }^{\circ} \mathrm{C}$. Protein $\mathrm{G}$ or A dynabeads (Invitrogen) were used for the immunoprecipitation according to the manufacturer's instructions. Briefly, $4 \mu \mathrm{l}$ antibody and $315 \mu \mathrm{g}$ protein were incubated in a tube rotator (Schuett 
Labortechnik) for $1 \mathrm{~h}$ at $4{ }^{\circ} \mathrm{C}$. Afterwards, $50 \mu \mathrm{l}$ of $50 \%$ slurry Dynabeads were added into each vial and incubated with rotation overnight at $4{ }^{\circ} \mathrm{C}$, followed by three washing steps before the target antigen could be eluted. Immunoprecipitated proteins $\left(2 \times 10^{6}\right.$ cells/protein $)$ were investigated by SDS-PAGE and western blotting.

\section{Enzymatic deglycosylation of $\operatorname{Pr} P^{C}$}

$\mathrm{PrP}^{\mathrm{C}}$-containing samples were deglycosylated using a glycoprotein deglycosylation kit (Calbiochem/Merck, Darmstadt, Germany). The procedure was carried out according to the manufacturer's instructions. After addition of reaction and denaturation buffer, samples were heated for $5 \mathrm{~min}$ at $95^{\circ} \mathrm{C}$. After cooling to room temperature, $\mathrm{N}$-glycosidase $\mathrm{F}$ was added. Thereafter, the samples were incubated for $3 \mathrm{~h}$ at $37^{\circ} \mathrm{C}$.

\section{Protein extracts preparation and subcellular fractionation}

Cells were washed, scraped in ice-cold PBS, and pelleted. Lysates were prepared using a buffer containing $50 \mathrm{mM}$ Tris- $\mathrm{HCl}, \mathrm{pH} 7.4,150 \mathrm{mM} \mathrm{NaCl}, 1 \%$ Triton X-100, and complete protease inhibitor cocktail (Roche, Indianapolis, IN, USA) for $15 \mathrm{~min}$ at $4 \mathrm{C}$, followed by $10 \mathrm{~min}$ centrifugation at $16,000 \mathrm{~g}$ at $4 \mathrm{C}$. The pellets, which were further used for the filter retardation assay, were resuspended in lysis buffer and sonicated. Subcellular fractionation was performed using a ProteoExtract Subcellular Proteome Extraction Kit (Calbiochem, San Diego, CA, USA) according to the manufacturer's instructions. Unless stated otherwise, cells were analyzed $24 \mathrm{~h}$ post-transfection. The immunoblotting was done with the following antibodies: AT8 AK (Thermoscientific, Bonn, dilution $1:$ 1000), anti-tau T46 (Invitrogen, dilution $1: 1000$ ), mouse anti-histone 2B (Abcam, Milton, GB, dilution $1: 2000$ ), mouse anti-beta actin (Abcam, dilution $1: 5000$ ), and mouse anti-cadherin (Sigma-Aldrich, St. Louis, USA, dilution $1: 2000$ ).

\section{SDS-PAGE and immunoblotting}

For western blot analysis, we used the monoclonal PrP antibodies SAF32 and 12F10 (SPI-Bio, Paris, France) diluted at 1:500; monoclonal antiA $\beta P P$ (Millipore, Schwalbach, Germany), polyclonal anti-BACE1, and polyclonal anti-p-tau Ser-396 (Acris Antibodies, Herford Germany) diluted at $1: 1000$; polyclonal anti-tau and polyclonal anti-p-tau
Thr-181 (Abcam, Cambridge, UK) diluted at 1:1000; monoclonal anti-p-tau Ser-199 (Roboscreen, Leipzig, Germany) diluted at 1:500; and monoclonal mouse anti- $\beta$-actin (Abcam) diluted at $1: 15000$. After adding loading buffer (Bio-Rad, Munich, Bavaria, Germany), samples were heated for $2 \mathrm{~min}$ at $95^{\circ} \mathrm{C}$.

Samples were separated by sodium dodecyl sulfate-polyacrylamide gel electrophoresis (SDSPAGE) $(12 \% \mathrm{w} / \mathrm{v}$ polyacrylamide) and transferred to polyvinylidene difluoride (PVDF) Hydrobond-P membranes (Amersham, Freiburg, Germany) using a semi-dry transblot cell (Bio-Rad) for $60 \mathrm{~min}$ at 12 Volt. Afterwards, PVDF-membranes were blocked with 5\% dried skimmed-milk powder in PBS and $0.1 \%$ Tween20 (PBST) for $1 \mathrm{~h}$ at room temperature and probed with the primary antibody overnight at $4{ }^{\circ} \mathrm{C}$. Membranes were washed in PBST and incubated with the corresponding horseradish peroxides conjugated secondary antibody (Jackson Immuno Research, Leipzig, Germany) diluted at $1: 10000$ for $1 \mathrm{~h}$. Protein bands were visualized after immersion of the membranes in enhanced chemiluminescence (ECL) detection solution and analyzed using the Chemi-Doc (Bio-Rad). All western blots shown are representative of at least three different and independent experiments.

\section{Analysis of $A \beta_{40}, s A \beta P P \beta$, and $s A \beta P P \alpha$ concentration by enzyme linked immunosorbent assay (ELISA)}

Levels of $A \beta_{40}$ were ascertained using the amyloid beta (1-40) (N)-assay and the highly specific mouse amyloid beta (1-40) ELISA obtained from (IBL, Hamburg, Germany). The amyloid beta (1-40) (N) assay kit is designed to measure full-length amyloid beta (1-40) peptides with an intact $\mathrm{N}$ terminus. It uses the antiamyloid beta (35-40) (1A10) antibody as the capture antibody and an HRP-conjugated anti-human $A \beta-(\mathrm{N})$ rabbit IgG polyclonal antibody as a detection antibody. Levels of $\mathrm{sA} \beta P P \beta$ were determined by the use of the anti-human sA $\beta P P \beta$ kit employing 6A1 mouse IgG and $\mathrm{SA} \beta \mathrm{PP} \alpha$ was analyzed by the anti-human $\mathrm{SA} \beta \mathrm{PP} \alpha$ kit with the monoclonal mouse IgG 2B3 (IBL, Hamburg, Germany).

All ELISA measurements were performed according to the protocol of the manufacturer. Samples with an adapted protein concentration of either 20 or $40 \mu \mathrm{g}$ total protein were sonicated and diluted in EIA buffer to a volume of $100 \mu \mathrm{l}$. The colorimetric reaction was measured at $450 \mathrm{~nm}$ with a 1420 Multilabel Counter Victor 2 (Wallac) (PerkinElmer, Massachusetts, USA). 
Analysis of tau and p-tau concentration

We used a tau and p-tau threonine Thr-231 multiplex assay as developed by Meso Scale DiscoveryTM (MSD) (Rockville, USA) and followed the manufacturer's instructions. The MSD ECL platform requires the use of special plates with embedded carbon ink electrodes. The principle of electrochemiluminescence is based upon electrochemical stimulation of an antibody SULFO-TAG label [ruthenium(II) trisbipyridine-(4-methylsulfonate) NHS ester] label. This leads to the emission of light at $620 \mathrm{~nm}$ which could be detected by a CCD camera in the MSD Sector Imagers.

After blocking with BSA for $1 \mathrm{~h}$, pre-coated plates were incubated with $40 \mu \mathrm{g}$ brain homogenate for $1 \mathrm{~h}$. After washing, the signal is detected using sulfo-tag labeled detection antibodies against tau and p-tau. The plates were analyzed using the MSD Sector Imager.

\section{Determination of the $\gamma$-secretase concentration}

We used a commercial Human $\gamma$-Secretase ELISA Kit (Cusabio, Wuhan, China) to analyze brain homogenates derived from Prnp0/0 and WT mice. The kit is based on ELISA techniques and is eligible for the qualitative determination of human $\gamma$-secretase. Brain homogenate samples were adapted to a total protein amount of $2 \mu \mathrm{g}$ and measured according to the manufacturer's instruction.

\section{Determination of the PrP concentration}

Sonicated cell samples were analyzed by a commercial BetaPrion BSE-ELISA Test Kit (AJ Roboscreen, Leipzig, Germany). The kit is based on ELISA techniques and is eligible for a rapid BSE test for the qualitative determination of $\mathrm{PrP}^{\mathrm{res}}$ in the brain of cattle and sheep. We omitted the proteinase (PK) digestion step. Our aim was to measure the concentration of total $\operatorname{PrP}^{\mathrm{C}}$. Cell samples were adapted to a total protein amount of $5 \mu \mathrm{g}$ and measured according to the manufacturer's instruction.

\section{Statistical analysis}

The quantification of the band intensities was performed by using the Scion Image software. All data were evaluated by the statistic software Graph Pad Prism 4. We calculated the $p$ values by using the $s t u$ dent's t-test for values which are normally distributed. Non-normally distributed values were analyzed by the Wilcoxon-Mann-Whitney-Test (Mann-WhitneyU-Test). The standard errors of the mean (SEM) were depicted as error bars. All values with $p<0.05$ were considered significant.

\section{RESULTS}

Interaction of $\operatorname{PrP}^{C}$ with $A D$ relevant proteins in HEK293 cells

The interaction of $\operatorname{PrP}^{\mathrm{C}}$ with $\mathrm{AD}$-relevant proteins (A $\beta P P$, tau, p-tau) was investigated in PRNPtransfected HEK293 cells.

Immunoprecipitation of $\operatorname{PrP}^{\mathrm{C}}$ using monoclonal $\mathrm{PrP}^{\mathrm{C}}$ antibody (SAF32) followed by western blotting with antibodies against A $\beta P P$, tau, p-tau Thr-181 and p-tau Ser-396 revealed a protein band of the expected molecular weight of the respective protein (Fig. 1). In addition, we examined the immunoprecipitates of A $\beta P$, tau, p-tau Thr-181, and Ser-396 for PrPC ${ }^{C}$ Their co-immunoprecipitation was indicative of a direct or an indirect interaction of $\operatorname{PrP}^{\mathrm{C}}$ with these proteins (Fig. 1).

For the detection of A $\beta P P$, we used the mAb 22C11, which recognizes full-length and a secreted isoform of AßPP (sA $\beta P P)$ (MW $100 \mathrm{kDa}$ ) [34, 35]. It is worth noting that we detected a faint band with the size of approximately $130 \mathrm{kDa}$ corresponding to full-length $\mathrm{A} \beta \mathrm{PP}$ and a more intensive band corresponding to sA $\beta P P$ (MW $100 \mathrm{kDa}$ ) in the $\operatorname{PrP}^{\mathrm{C}}$ immunoprecipitate (Fig. 1A). These data indicated that sA $\beta P P$ possesses a higher affinity to $\mathrm{PrP}^{\mathrm{C}}$ than full-length $\mathrm{A} \beta \mathrm{PP}$.

No interaction was evident when the Dynabeads were incubated with non-specific mouse or rabbit IgG. For each protein, total protein extracts (Input) showed the same molecular weight of the analyzed proteins (Fig. 1).

Impact of $\operatorname{PrP}^{C}$ on the expression of $A \beta P P$, $B A C E 1$, and on $A \beta P P$ cleavage fragments

HEK293 cells were transiently transfected with the pCMS-PRNP-EGFP vector, expressing human $P R N P$ and an empty pCMS-EGFP vector [31]. Western blot analysis of cell lysates using the monoclonal antibody SAF32 demonstrated the expression of $\operatorname{PrP}^{\mathrm{C}} 24 \mathrm{~h}$ and $48 \mathrm{~h}$ after transfection as compared to control cells that exhibit the endogenous level of $\operatorname{PrP}^{\mathrm{C}}$ (Fig. 2A1). We observed a molecular weight of $27 \mathrm{kDa}$ for the unglycosylated, $33 \mathrm{kDa}$ for the monoglycosylated, and $35 \mathrm{kDa}$ for the diglycosylated $\mathrm{PrP}^{\mathrm{C}}$ isoform. Treatment with N-glycosydase F (PNGase F) was used to deglycosylate $\mathrm{PrP}^{\mathrm{C}}$ and to prove the specificity of the $\mathrm{PrP}^{\mathrm{C}}$ detection (Fig. 2A2). A densitometric evaluation of the band intensities as well as the determination of the 

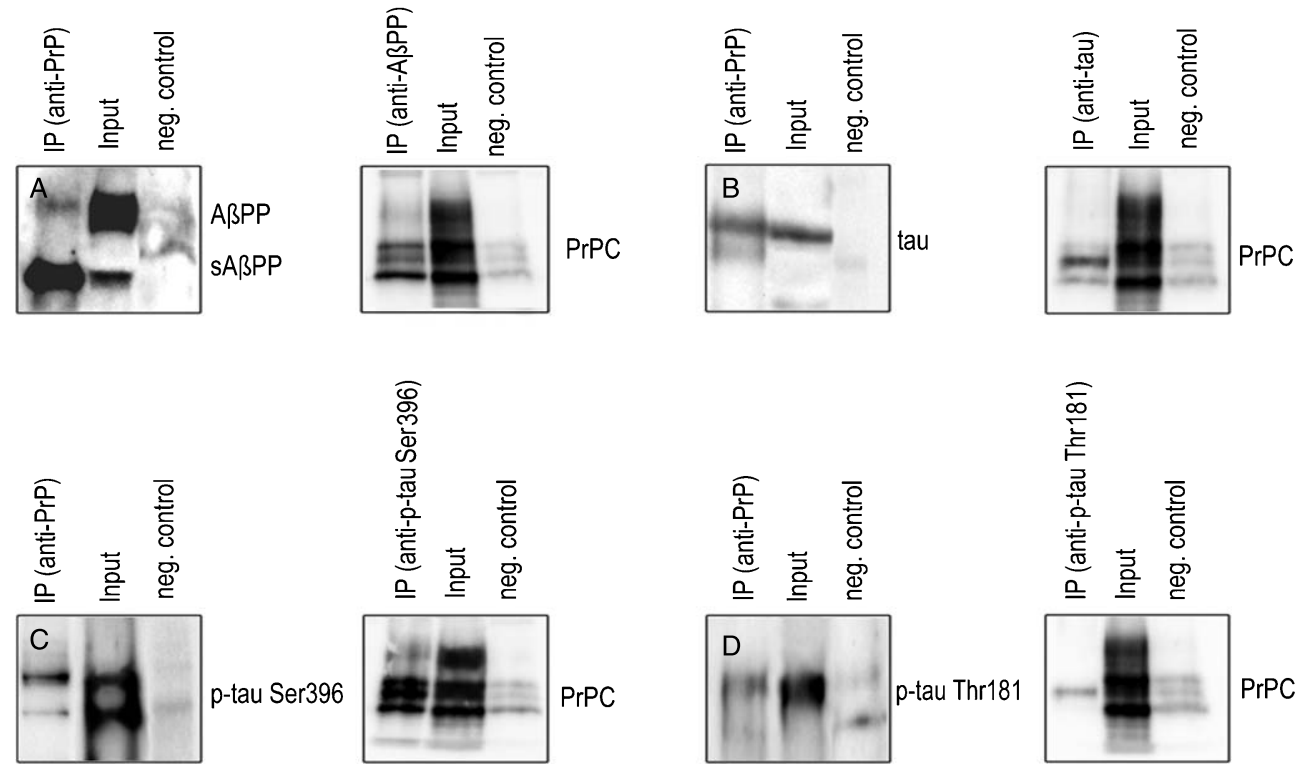

Fig. 1. Interaction of $\operatorname{PrP}^{\mathrm{C}}$ with $\mathrm{s} A \beta P P, \mathrm{~A} \beta \mathrm{PP}$, tau, and p-tau. Lysates from $\operatorname{PrP}^{\mathrm{C}}$ overexpressing HEK293 cells were immunoprecipitated (IP) first with anti-PrP SAF32 and secondly with the indicated antibodies. As potential interacting partners of $\operatorname{PrP}^{\mathrm{C}}$, the proteins $\mathrm{A} \beta \mathrm{PP}$ and $\mathrm{sA} \beta \mathrm{PP}$ (A), tau (B), p-tau Ser-396 (C), and p-tau Thr-181 (D) could be identified by western blotting. Total protein extract from cell lysates (Input) was loaded as a positive internal control of electrophoretic mobility and antibody specificity. The negative control, consisting of beads without antibody, was shown for each antibody. All IPs were triplicates.

$\mathrm{PrP}^{\mathrm{C}}$ concentration revealed a significant upregulation of $\mathrm{PrP}^{\mathrm{C}}$ level between 3.5-4 fold $48 \mathrm{~h}$ after transfection (Figs. 2A1 and 3).

Moreover, we examined the expression of A $\beta P P$ and BACE1 using immunoblotting in the same samples and showed that $\operatorname{PrP}^{\mathrm{C}}$ had no impact on the expression of both proteins (Fig. 2B). The intra- and extracellular (conditioned cell media) levels of the A $\beta P P$ cleavage fragments $A \beta_{40}$ and $\mathrm{s} A \beta P P \beta$, indicators for the amyloidogenic processing pathway, and sA $\beta P P \alpha$, an indicator for the non amyloidogenic processing pathway of A $\beta P P$, were determined by ELISA (Fig. 2C). Overexpression of $\mathrm{PrP}^{\mathrm{C}}$ resulted in a significant decrease of $\mathrm{A} \beta_{40}, \operatorname{sA} \beta \mathrm{PP} \beta$, and $\mathrm{sA} \beta \mathrm{PP} \alpha$ of approximately $20-30 \%$ as compared to control cells (Fig. 2C1-3). We confirmed these findings in the neuroblastoma cell line SH-SY5Y (Supplementary Fig. 1A-D).

In vivo studies were carried out on brain samples derived from Prnp0/0 mice and WT mice at an age of 3 and 15 months. The quantification of protein bands in the western blot confirmed our observation that the presence or absence of $\mathrm{PrP}^{\mathrm{C}}$ did not influence A $\beta P P$ or BACE levels and this effect does not depend on age (Fig. 2D). When we analyzed the level of $A \beta_{40}$ by ELISA, it could be observed that PrnpO/O mice (at 3 and 15 months of age) contained a significant higher amount of $A \beta_{40}(40-50 \%)$ than WT animals of the same age (Fig. 2E1). Independently of $\operatorname{PrP}^{\mathrm{C}}$, no significant differences could be observed between young and old animals (Fig. 2E1).

As a further control, we used $\operatorname{PrP}^{\mathrm{C}}$ overexpressing $\mathrm{Tg} 35$ mice, which showed a significant decreased level of $\mathrm{A} \beta_{40}$ compared to WT and Prnp0/0 mice (Fig. 2E2). The concentration of $\gamma$-secretase was measured in WT and Prnp0/O mice ( 3 months) by ELISA and revealed no significant abnormalities in Prnp0/0 mice (Fig. 2E3). Since we used a non-AD-model, the amount of $A \beta_{42}$ was below the detection limit of the ELISA and therefore excluded from our study.

\section{$\operatorname{PrP}^{C}$ reduces levels of 3PO-tau and p-tau and increases cell survival}

3PO-tau is a mutant form of the full length tau protein. In this mutant, three single amino acid changes were made in the microtubule binding repeats that break predicted $\beta$-sheet-forming patterns of alternating polar and apolar amino acids, i.e., the mutant was three times pattern-optimized (3PO) for aggregation. These regions were later confirmed to contain $\beta$-sheet structure by solid-state NMR [36]. 3PO was shown in different cell types to form stable tau aggregates with highly phosphorylated tau protein, disruption of the 
A

1
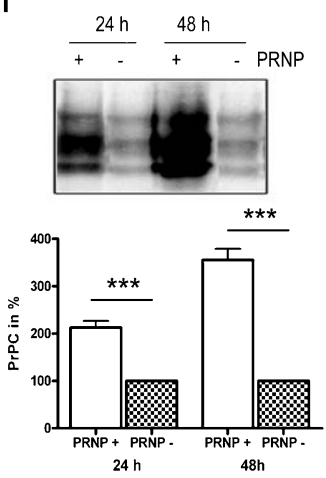

B

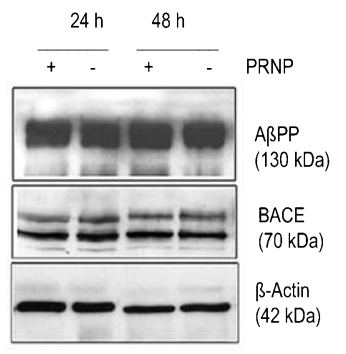

D

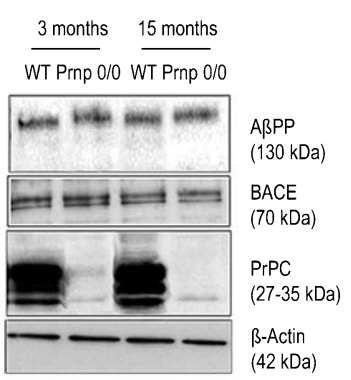

2

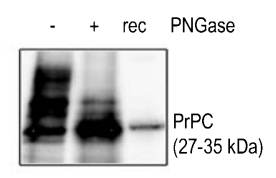

3

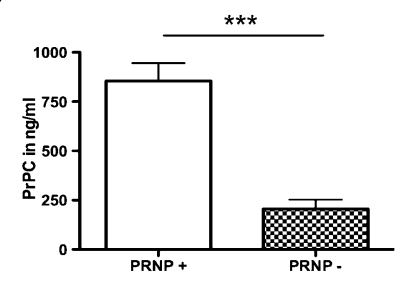

C

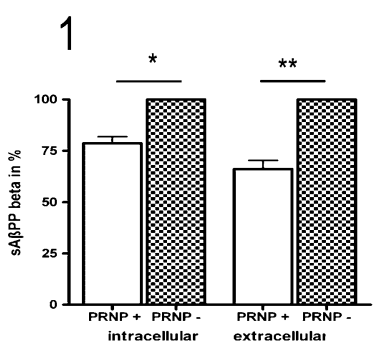

2
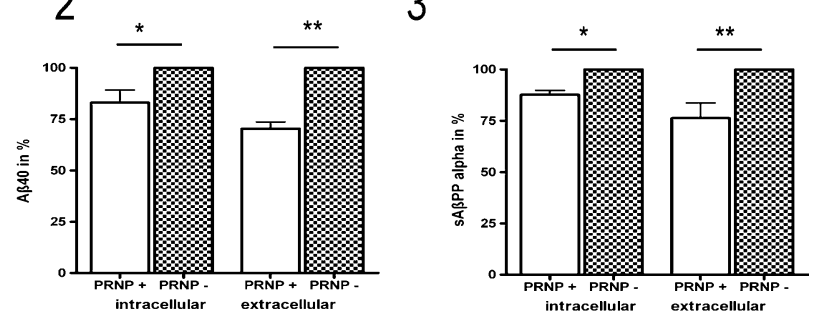

3

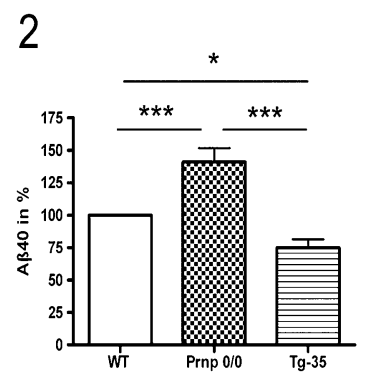

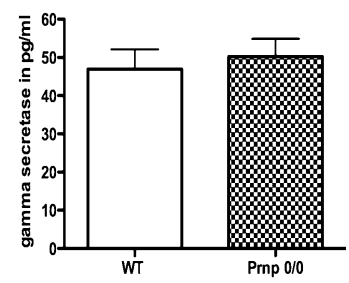

Fig. 2. Effect of $\operatorname{PrP}^{\mathrm{C}}$ on the expression of A $\beta P P, B A C E 1, A \beta_{40}, \mathrm{sA} \beta P P \beta$, and $\mathrm{sA} \beta P P \alpha$. A) PrP ${ }^{\mathrm{C}}$ overexpressing HEK293 cells were analyzed 24 and $48 \mathrm{~h}$ after transfection by western blotting in comparison to control cells (1). Quantification of the band-intensity showed that $\operatorname{PrP}^{\mathrm{C}}$ was approximately 2 -fold upregulated $24 \mathrm{~h}$ - and approximately 3.5 fold upregulated $48 \mathrm{~h}$ after transfection (1). Treatment with PNGase resulted in a deglycosylation of $\mathrm{PrP}^{\mathrm{C}}$ to prove the specificity of the $\operatorname{PrP}^{\mathrm{C}}$ detection (2). Concentration of $\operatorname{PrP}^{\mathrm{C}}$ was determined $48 \mathrm{~h}$ after transfection using a PrP ELISA-assay (3). B) Expression of A $\beta P P$ and BACE1 was analyzed 24 and $48 \mathrm{~h}$ after transfection by western blotting. Both proteins were not influenced by the expression of $\mathrm{PrP}^{\mathrm{C}}$. C) Amount of A $\beta$ PP-cleavage fragments were measured via ELISA. Intra- and extracellular levels of $\mathrm{A} \beta_{40}, \mathrm{sA} \beta P P \beta$, and $\mathrm{sA} \beta \mathrm{PP} \alpha$ were decreased significantly in $\mathrm{PrP}^{\mathrm{C}}$ over-expressing cells (1-3). All in vitro experiments were carried out at least in triplicates. D) In mice, analysis of AßPP and BACE1 expression revealed no differences between Prnp0/0 and WT mice. E) ELISA measurement of $A \beta_{40}$ generation in mice brains revealed a marked, age-independent increase in Prnp0/0 mice compared to WT animals (1). $\mathrm{PrP}^{\mathrm{C}}$ overexpressing Tg35 mice revealed a decreased level of $\mathrm{A} \beta_{40}$ (2) whereas concentration of $\gamma$-secretase remained unchanged in Prnp0/0 mice (3). All values were calculated in \% of WT. Beta actin was used as an internal standard. For comparison between groups we used the student's t-test ( $n=5$ per group in three independent experiments). Error bars indicate standard errors of the mean (SEM).

microtubule network, and strong cell death [31]. 3POtau expression in rodent brain using viral delivery also produced a strong AD-like pathology [37].
In the present study, we transiently co-transfected HEK293 cells with 3PO-tau and PRNP. Control cells were transfected with 3PO-tau and an empty vector 
(lacking the PRNP gene). To investigate the cellular distribution of 3PO-tau, we performed a subcellular fractionation into cytosolic, membranous/organellar, nuclear, and cytoskeletal fractions. Afterwards, expression of 3PO-tau (Fig. 3A) and p-tau (Fig. 3B) were analyzed by western blotting. In addition to a band running at $75 \mathrm{kDa}$, which probably corresponds to monomeric full length 3PO-tau, we could detect several protein bands between 20 and $30 \mathrm{kDa}$, which we consider to be proteolytical tau fragments. In 3POtau transfected cells, we observed additional bands at 20-25 kDa, which likely indicated an increased fragmentation of 3PO-tau (Fig. 3A). The expression of these tau forms was depicted $60 \mathrm{~h}$ after transfection. Band intensities of the immunoblots were quantified using densitometric analysis. Interestingly, 3PO-tau and p-tau were found equally abundant in the cytosolic and cytoskeletal fractions, which are of particular interest, because the main toxicity of tau in $\mathrm{AD}$ is related to the destruction of the microtubule system. They were less abundantly detectable in the membrane/organelle fractions (Fig. 3A, B).

Our data revealed that overexpression of $\mathrm{PrP}^{\mathrm{C}}$ resulted in a significant decrease of 3PO-tau and its phosphorylated forms ( $\mathrm{p}$-tau) in all subcellular compartments (Fig. 3A, B), indicating a protective role of $\mathrm{PrP}^{\mathrm{C}}$ in tau metabolism and tau induced $\mathrm{AD}$ like pathology. Even though $\operatorname{PrP}^{\mathrm{C}}$ is a ubiquitously expressed protein, the amount of tau down regulation also depends on the cellular environment; in particular the cytoskeleton-associated 3PO-tau and p-tau levels were decreased when cells were co-transfected with $\operatorname{PrP}^{\mathrm{C}}$ (Fig. 3A, B). Aggregated 3PO-tau can be observed in the cytoskeletal fraction as a band over the prominent $70 \mathrm{kDa}$ monomeric protein band (Fig. 3A). Expression of $\operatorname{PrP}^{\mathrm{C}}$ completely eliminates this higher fraction, suggesting that tau aggregation is reduced.

In accordance with the lower overall 3PO-tau levels, its phosphorylation and aggregation, toxicity in 3POtau- $P R N P$-co-transfected cells was significantly lower than in control cells co-transfected with 3PO-tau and an empty vector. This could be shown in a crystal violet cell survival assay. Here, a co-transfection with PRNP resulted in a significantly increase of the survival rate of these cells (Fig. 3C).

Additionally, we also found that overexpression of $\mathrm{PrP}^{\mathrm{C}}$ resulted in a significant decrease of WTtau in all subcellular compartments (Supplementary Fig. 3). This seems to indicate that $\operatorname{PrP}^{\mathrm{C}}$ exerts its neuroprotective effect by mechanisms that act on both non-pathological and pathological tau. It should be noted that high expression levels of tau are neuro- toxic [38] and this may indicate that $\operatorname{PrP}^{\mathrm{C}}$ also plays a protective role in these forms of tauopathies.

\section{Effect of $\operatorname{PrP}^{C}$ on tau and p-tau levels during aging and under oxidative stress conditions}

We examined the effect of $\operatorname{PrP}^{\mathrm{C}}$ on the expression of tau and p-tau in brain tissue derived from WT and Prnp0/O mice under both aging and oxidative stress conditions.

Expression of tau and p-tau Ser-199 in cortex, hippocampus, and cerebellum were illustrated by immunohistochemical staining. $\operatorname{PrP}^{\mathrm{C}}$ had no significant effect on tau and p-tau localization as is depicted by the signal intensities and patterns observed in Fig. 4A.

The concentration of tau and p-tau Thr-231 in brain tissue of Prnp0/O and WT mice was determined by a MSD-electrochemiluminescence based assay. While aging (after 3 and 15 months) had no effect on tau and p-tau level neither in Prnp0/0 nor in WT mice (Fig. 4B; Supplementary Fig. 2A), we observed an effect of $\operatorname{Pr}^{\mathrm{C}}$ on the expression of tau under oxidative stress conditions (Fig. 4C). Six and $24 \mathrm{~h}$ after induction of a $60 \mathrm{~min}$ stroke, brain homogenates were analyzed by MSD-electrochemiluminescence based assay for tau and p-tau Thr-231. Interestingly, in Prnp0/0 mice, the tau level increased after 6 and $24 \mathrm{~h}$ reperfusion as compared to normoxic Prnp0/0 mice and WT mice under the same conditions (Fig. 4C). Levels of p-tau Thr-231 remained unchanged by $\operatorname{PrP}^{\mathrm{C}}$ (Fig. 4C). An overview of the different p-tau isoforms is given in Supplementary Table 1.

\section{DISCUSSION}

Both $\mathrm{AD}$ and CJD are neurodegenerative diseases caused by conformational changes in specific proteins that alter their function. Co-existence of AD pathology in prion diseases such as CJD has already been shown [39] and a potential role of $\operatorname{PrP}^{\mathrm{C}}$ in AD-like pathology is widely discussed [22-24].

However, the exact function of $\operatorname{PrP}^{\mathrm{C}}$ on $\mathrm{AD}$-relevant pathways has not yet been completely understood. The present study was undertaken to gain new insights into the physiological role of $\mathrm{PrP}^{\mathrm{C}}$ and its interactions with proteins involved in the $A \beta$ cascade hypothesis and in the development of tau pathology. In particular, we were interested in examining whether $\operatorname{PrP}^{\mathrm{C}}$ may interact or regulate the expression of $\mathrm{AD}$-relevant proteins namely $\mathrm{A} \beta \mathrm{PP}, \mathrm{BACE} 1, \mathrm{~A} \beta$, tau, or $\mathrm{p}$-tau. We also analyzed the impact of $\operatorname{PrP}^{C}$ on the processing of 
A

cytosolic membranous nuclear cytoskeletal

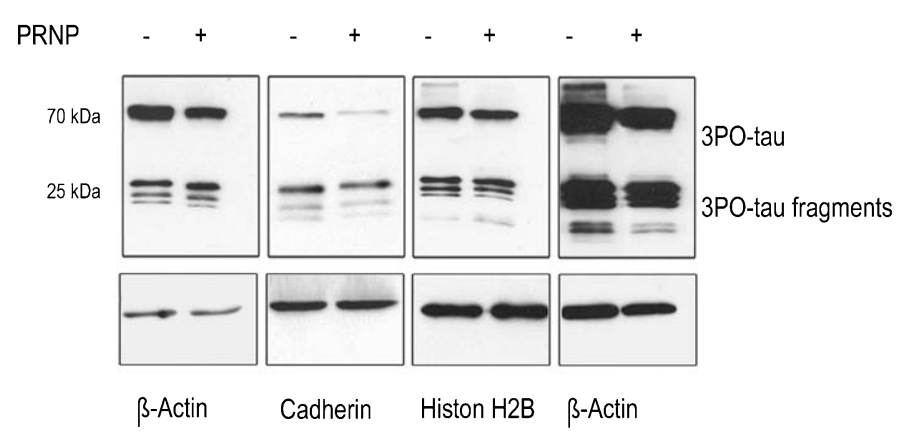

B

cytosolic membranous nuclear cytoskeletal

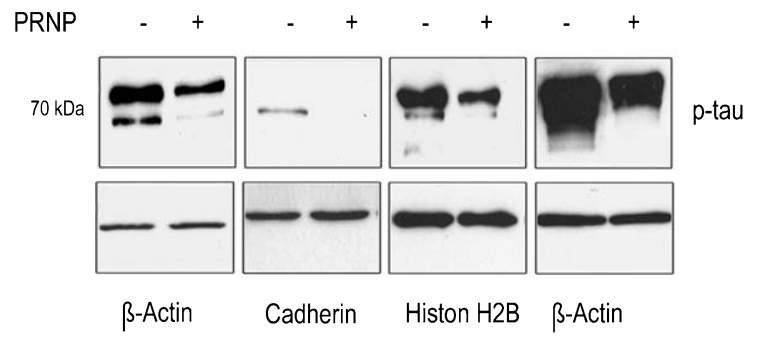

C

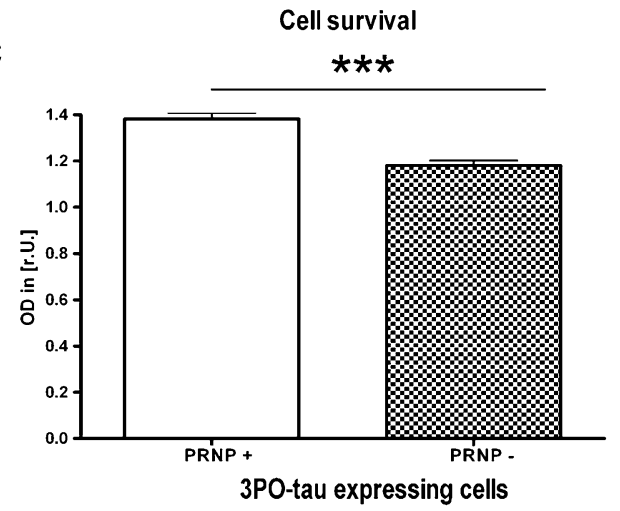

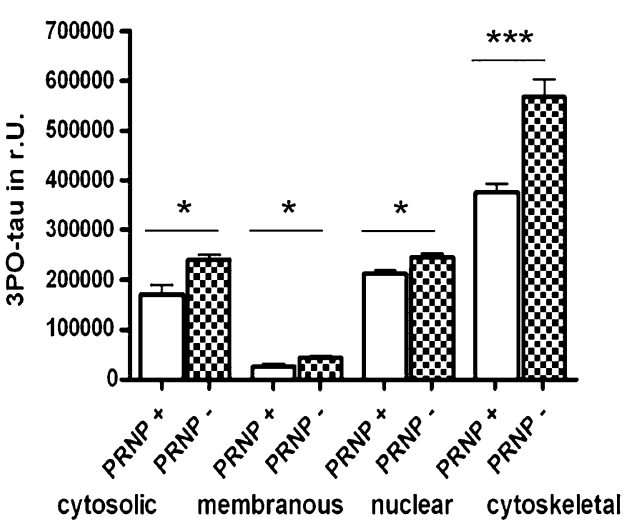

P-tau

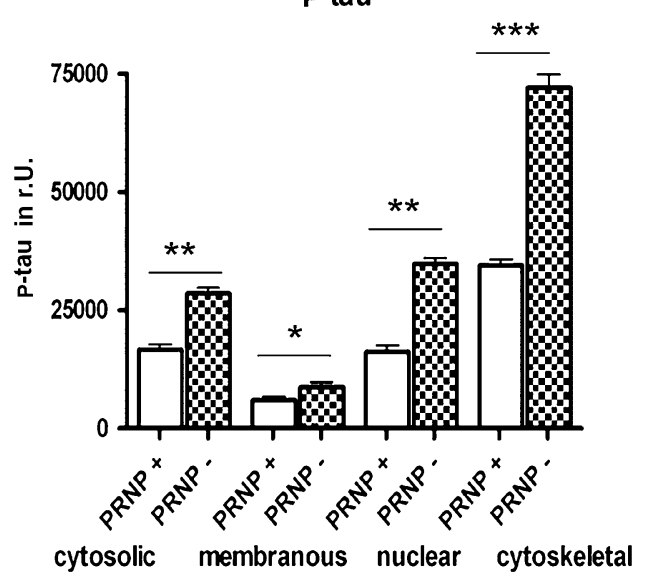

Fig. 3. Effect of $\mathrm{PrP}^{\mathrm{C}}$ concentration on the expression of 3PO-tau and p-tau in different subcellular compartments. HEK293 cells were cotransfected with $3 \mathrm{PO}$-tau and PRNP in comparison to control cells (3PO-tau and an empty control vector, designated as PRNP-), subjected to subcellular fractionation and immunoblotting. Four subcellular fractions (cytosolic, membranous/organelle, nuclear, and cytoskeletal) of co-transfected cells were analyzed $60 \mathrm{~h}$ after transfection by western blotting using the anti-C-terminal anti-tau T46 and anti-p-tau AT8. We used compartment-specific proteins as loading controls (bottom). A) Densitometric quantification of the band intensities revealed that 3PO-tau levels were significantly reduced in all subcellular compartments after $60 \mathrm{~h}$, when $\mathrm{PrP}^{\mathrm{C}}$ was overexpressed compared to control cells exhibiting an endogen PrP ${ }^{C}$ expression. B) Quantification of p-tau level (Thr-205 and Ser-202) of 3-PO tau co-transfected cells showed a decreased amount of p-tau in all cellular compartments when $\mathrm{PrP}^{\mathrm{C}}$ is overexpressed compared to control cells exhibiting an endogen $\mathrm{PrP}^{\mathrm{C}}$ expression. Densitometric analyses were performed from at least three different western blots. C) Co-transfected 3PO-tau cells (either with PRNP or with an empty vector) were cultivated for $60 \mathrm{~h}$ and analyzed in a crystal violet cell survival assay. Cellular survival was significantly increased in $P R N P+$ cells in comparison to control cells (PRNP-). Cell survival was measured in triplicates, $n=20$. For comparison between groups we used the student's $t$-test. Error bars indicate standard errors of the mean (SEM). 


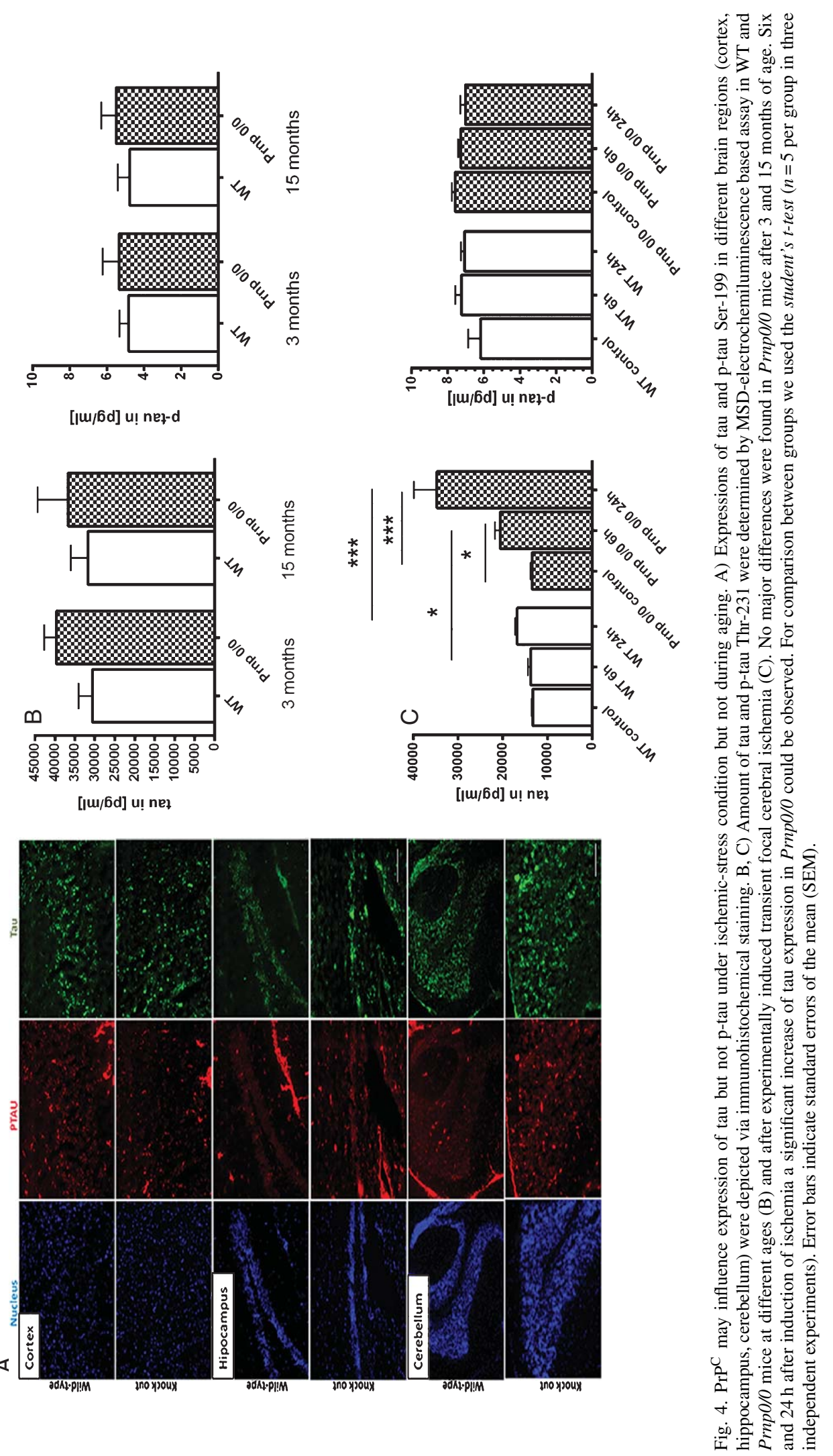


A $\beta P P$ under physiological conditions without amyloid pathology.

\section{$\operatorname{PrP}^{C}$ may inhibit the cleavage of $A \beta P P$ via interaction with $B A C E 1$ and $A \beta P P$}

The amyloid cascade hypothesis [42] implies that $\mathrm{A} \beta$ generation and deposition are the central events in the progression of $\mathrm{AD}$. $\mathrm{A} \beta$ is formed during the amyloidogenic pathway of A $\beta P P$ processing by cleavage of A $\beta P P$ via $\beta$-secretase and $\gamma$-secretase. Recent studies on AD models indicated a causal involvement of $\mathrm{PrP}^{\mathrm{C}}$ in the amyloid pathogenesis of $\mathrm{AD}[40,41]$.

One of the caveats of the $\mathrm{A} \beta P P_{\text {mut }}$ model are reports demonstrating that murine $\operatorname{PrP}^{\mathrm{C}}$ has a different effect on the processing of $A \beta P P_{W T}$ and $A \beta P P_{\text {mut }}$ [43] and fails to reduce levels of $A \beta$ and $A \beta$ deposits in trans-

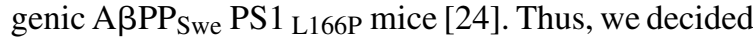
to use an alternative non-amyloid model to study the potential function of $\mathrm{PrP}^{\mathrm{C}}$.

Under our experimental conditions, both the $\alpha$ - and $\beta$-secretase pathways were inhibited by $\operatorname{PrP}^{\mathrm{C}}$ indicating an unspecific inhibition of the A $\beta P P$ cleavage.

However, the observed reduction after $\mathrm{PrP}^{\mathrm{C}}$ upregulation in $A \beta$ levels were more evident (up to 90\%) in models using mutated $\mathrm{A} \mathrm{PP}_{695}$ expressing cells [40] as compared to a physiological A $\beta P P$ model, employed in this study, where the observed reduction in the levels of intra- and extracellular $\mathrm{A} \beta_{40}, \operatorname{sA} \beta \mathrm{PP} \alpha$, and $\mathrm{sA} \beta \mathrm{PP} \beta$ was approximately $25-30 \%$. A reason might be that non-transfected HEK293 cells express a physiological level of A $\beta P P$. We conclude that the impact of $\mathrm{PrP}^{\mathrm{C}}$ on the physiological $\mathrm{A} \beta \mathrm{PP}$ processing seems to be moderate. The detection of amyloid fragments in the cell media indicates that the intracellular concentration of A $\beta P P$ cleavage fragments might be regulated via secretion.

In mice, we observed that $\operatorname{PrP}^{\mathrm{C}}$ may influence the processing of $A \beta P P$ as indicated by a reduction in the amount of the $A \beta P P$ cleavage fragment $A \beta_{40}$ without changing the concentration of $\gamma$-secretase. Brains of WT mice, independent of their age, contained a significantly lower amount of $\mathrm{A} \beta_{40}$ compared to PrnpO/O mice, which is in line with our in vitro data. Interestingly, $\operatorname{PrP}^{\mathrm{C}}$-overexpressing $\mathrm{Tg} 35$ mice showed a further decrease of $A \beta_{40}$ levels when compared to WT mice. Others who housed the Prnp0/O mouse line, Edinburgh 1 [40], are comparable to our findings, showing that the regulation of $A \beta$ is independent of the mouse strain.

Our observation that A $\beta P P$ or BACE1 level remained unchanged by $\operatorname{PrP}^{C}$, even though the amount of several cleavage products was increased, is in line with other groups $[24,40]$. One explanation may be that A $\beta P P$ metabolism is more complex, e.g., A $\beta P P$ can be processed by different pathways. Not all were influenced by $\operatorname{PrP}^{\mathrm{C}}$.

Another possibility to influence A $\beta P P$ processing is via protein interaction which was investigated more detailed. Our data indicate that $\operatorname{PrP}^{\mathrm{C}}$ can potentially interact with both proteins. While the $\operatorname{PrP}^{\mathrm{C}}$ interaction with a pro-domain of an immature Golgiassociated form of BACE1, which may restrain BACE1 in the trans-Golgi network, had already been described previously [43], we additionally found that $\mathrm{PrP}^{\mathrm{C}}$ might influence $\mathrm{A} \beta P P$ processing by binding to $\mathrm{A} \beta \mathrm{PP} / \mathrm{sA} \beta \mathrm{PP}$ or the amyloid domain within A $\beta P P$. Our immunoprecipitation analysis revealed that $\mathrm{PrP}^{\mathrm{C}}$ interacts with a secreted isoform of $\mathrm{A} \beta \mathrm{PP}$ (sA $\beta \mathrm{PP}$ ) as well as with full-length $\mathrm{A} \beta P P$. However, the $\operatorname{PrP}^{\mathrm{C}}$ $\mathrm{A} \beta \mathrm{PP}$ was faint in comparison to the $\mathrm{PrP}^{\mathrm{C}}$-sA $\beta P P$ interaction. Conformational changes within full-length $\mathrm{A} \beta \mathrm{PP}$, which may at least partly bury the binding epitope of $\mathrm{PrP}^{\mathrm{C}}$, might serve as an explanation. Other studies which documented that $\operatorname{PrP}^{\mathrm{C}}$ interacts with $\mathrm{A} \beta$ [22] or with an A $\beta P P-l i k e$ protein (Aplp1), which contains sequence similarities to A $\beta P P$ [44], are in line with our findings.

Our data suggest that the binding of $\operatorname{PrP}^{\mathrm{C}}$ to $\mathrm{A} \beta \mathrm{PP}$ and the amyloid domain within A $\beta P P$ may restrict the access for the processing secretase and impede the generation of amyloid fragments. In addition, an inhibition of BACE1 activity via $\operatorname{PrP}^{\mathrm{C}}$ has already been reported $[40,45]$. Furthermore, $\operatorname{PrP}^{\mathrm{C}}$ is described as a physiological substrate of $\alpha$-secretase. Its cleavage yields a number of $\mathrm{PrP}^{\mathrm{C}}$ fragments [46] and can occur in competition with $\mathrm{A} \beta \mathrm{PP}$, showing that there might be different ways in which $\operatorname{PrP}^{\mathrm{C}}$ may influence the processing of $\mathrm{A} \beta \mathrm{PP}$.

Remarkably, Vincent et al. detected a negativefeedback mechanism by which presenilins, the catalytic subunit of the $\gamma$-secretase complex, may control the transcription of $\operatorname{PrP}^{\mathrm{C}}$ [47]. An increase of the amyloid intracellular domain (AICD), generated during the processing of A $\beta P P$ by $\gamma$-secretase, can induce a p53-dependent upregulation of $\operatorname{PrP}^{\mathrm{C}}$ mRNA level $[47,48]$.

\section{Enhanced $\operatorname{PrP}^{C}$ levels may reduce the $A D$-like tau pathology}

By regulating microtubule assembly and stabilization, tau can modulate cell motility and the efficacy of motor-driven transport processes [49]. AD and CJD 
share several neuropathological characteristics. In particular, hyperphosphorylated tau deposits have been observed in a population of patients with GerstmannStraussler-Scheinker syndrome (GSS) bearing a certain point mutation on PRNP [50]. Immunohistochemical analysis had demonstrated a co-localization of p-tau and PrP in GSS [51], and it had also been shown that some mutated forms of PrP can form a complex with tau $[52,53]$. These findings raise the question as to whether $\mathrm{PrP}^{\mathrm{C}}$ might be involved in the regulation of tau protein and if the $\mathrm{PrP}^{\mathrm{C}}$-tau interaction may change the pathological characteristics of tau.

In our study, we identified two p-tau isoforms, Thr181 and Ser-396, as potential interacting partners of $\mathrm{PrP}^{\mathrm{C}}$. An increased phosphorylation of tau at Thr-181 was shown to be an early event in the development of AD [54] and Ser-396 phosphorylation of tau is primarily responsible for the functional loss of tau-mediated tubulin polymerization [55].

Moreover, we confirmed the interaction of $\mathrm{PrP}^{\mathrm{C}}$ and tau [30] in which the octa-repeat region of $\mathrm{PrP}^{\mathrm{C}}$ and the $\mathrm{N}$-terminus (1-91) or the tandem repeats region (amino acids 186-283) of tau are most probably involved [52].

A previous study even provided evidence that $\operatorname{PrP}^{C}$ may be involved in $\mathrm{A} \beta$-induced hyperphosphorylation of tau [53], which strongly provides hints for an important role of $\mathrm{PrP}^{\mathrm{C}}$ in $\mathrm{AD}$.

To explore the role of $\mathrm{PrP}^{\mathrm{C}}$ in tau pathology, we used a PrPC ${ }^{C}$ overexpressing HEK293 cell model cotransfected with a 3PO-tau plasmid. The 3PO-tau model had been previously established for the investigation of the molecular mechanisms of tau pathology [31]. It is based on point mutations of intermitting breaking sequences of the microtubule-binding repeats of tau producing a rapid aggregation and cytotoxicity with accompanying occurrence of pathologic tau [31].

Interestingly, we found that the amount of 3POtau and p-tau (Ser-202 and Thr-205, both are AD-associated abnormal phosphorylation sites) was markedly reduced in different subcellular compartments when $\mathrm{PrP}^{\mathrm{C}}$ is overexpressed, in particular within the cytoskeleton. Toxic effects of 3PO-tau were correlating with these findings, because a down regulation of 3PO-tau and p-tau in $\operatorname{PrP}^{\mathrm{C}}$ overexpressing cells resulted in an increased cell survival compared to controls exhibiting an endogenous $\operatorname{PrP}^{\mathrm{C}}$ level. Since the level of WT-tau was also modulated by $\operatorname{PrP}^{\mathrm{C}}$ level, our data indicate an inhibitory and protective function of $\operatorname{PrP}^{\mathrm{C}}$ under cellular stress condition induced by an increased level of tau.

To test this hypothesis, we examined the expression of tau and different forms of p-tau (Thr-181, Thr-231,
Ser-199, and Ser-396) in a transgenic mice model lacking $\operatorname{PrP}^{C}$. The regulation of tau phosphorylation is of utmost relevance for mediation of dynamic instabilities of microtubules. However, the expression of different p-tau isoforms, caused by different kinase activities, may differ in brains of scrapie infected hamsters [56], which was the reason why we analyzed different $\mathrm{p}$-tau isoforms.

In our study we found that during the aging process, tau and p-tau levels were not abnormally changed in the brains of Prnp0/0 mice compared to WT mice. Interestingly, under ischemic stress conditions, we observed a significant increase of tau in PrnpO/O mice which fits to our in vitro data.

The fact that $\operatorname{PrP}^{\mathrm{C}}$ confers cell protection under cellular stress conditions is meanwhile widely accepted $[14,57,58]$. Under normal conditions, however, $\operatorname{PrP}^{\mathrm{C}}$ seems to be less functional [33].

In this context, it remains elusive if $\operatorname{PrP}^{\mathrm{C}}$ can suppress the production of tau, increase its proteolytical clearance, or even attenuate the aggregation of tau in $\mathrm{AD}$. The observed reduction in a higher molecular weight form of 3PO-tau upon expression of $\operatorname{PrP}^{\mathrm{C}}$ seems to suggest that this might be the case. A previous study showed a protective effect of $\operatorname{PrP}^{\mathrm{C}}$ in huntingtin pathology. The outcome of this study that overexpression of $\mathrm{PrP}^{\mathrm{C}}$ reduces huntingtin aggregation and toxicity in neuronal cells [59] fits our observations. The fact that a depletion of $\operatorname{PrP}^{\mathrm{C}}$ causes a reduction in antioxidant enzymes and proteasome activity $[59,60]$ indicates that $\mathrm{PrP}^{\mathrm{C}}$ might regulate the degradation process of 3PO-tau or p-tau. However, the exact molecular mechanism responsible for attenuation of 3PO-tau in $\mathrm{PrP}^{\mathrm{C}}$ overexpression cells remains to be elucidated.

In conclusion, our data provide evidence for a protective function of $\operatorname{PrP}^{\mathrm{C}}$ in $\mathrm{AD}$. On the one hand, $\operatorname{PrP}^{\mathrm{C}}$ may reduce the amount of potential harmful $\mathrm{A} \beta \mathrm{PP}$ cleavage fragments and, on the other, it attenuates the production of tau in vitro. However, whether these findings can be assigned to an in vivo AD mice model or to $\mathrm{AD}$ patients requires further investigation.

\section{ACKNOWLEDGMENTS}

This work was supported by a grant from the European Commission: Protecting the food chain from prions: shaping European priorities through basic and applied research (PRIORITY, $\mathrm{N}^{\circ}$ 222887) Project number: FP7-KBBE-2007-2A. The study was performed within the recent established Clinical Dementia Center at the University Medical School and was 
partly supported by grants from the JPND program (DEMTEST (Biomarker based diagnosis of rapid progressive dementias-optimization of diagnostic protocols, 01ED1201A)), from the Federal Ministry of Education and Research grant within the German Network for Degenerative Dementia, KNDD-2, 20112013, Determinants for disease progression in AD, as well as from the Alzheimer-Forschungs-Initiative e.V. (AFI 12851).

Authors' disclosures available online (http://www.jalz.com/disclosures/view.php?id=1883).

\section{SUPPLEMENTARY MATERIAL}

Supplementary figures and tables are available in the electronic version of this article: http://dx.doi.org/ 10.3233/JAD-130566.

\section{REFERENCES}

[1] Tobler I, Gaus SE, Deboer T, Achermann P, Fischer M, Rulicke T, Moser M, Oesch B, McBride PA, Manson JC (1996) Altered circadian activity rhythms and sleep in mice devoid of prion protein. Nature $\mathbf{3 8 0}, 639-642$.

[2] Brown DR, Qin K, Herms JW, Madlung A, Manson J, Strome R, Fraser PE, Kruck T, von Bohlen A, Schulz-Schaeffer W, Giese A, Westaway D, Kretzschmar H (1997) The cellular prion protein binds copper in vivo. Nature 390, 684-687.

[3] Brown DR, Schmidt B, Kretzschmar HA (1997) Effects of oxidative stress on prion protein expression in PC12 cells. Int J Dev Neurosci 15, 961-972.

[4] Peters PJ, Mironov A Jr, Peretz D, van Donselaar E, Leclerc E, Erpel S, DeArmond SJ, Burton DR, Williamson RA, Vey M, Prusiner SB (2003) Trafficking of prion proteins through a caveolae-mediated endosomal pathway. J Cell Biol 162, 703717.

[5] Toni M, Spisni E, Griffoni C, Santi S, Riccio M, Lenaz P, Tomasi V (2006) Cellular prion protein and caveolin-1 interaction in neuronal cell line precedes Fyn/Erk1/2 signal transduction. J Biomed Biotechnol 69469, 1-13.

[6] Schmitz M, Klöppner S, Klopfleisch S, Möbius W, Schwartz P, Zerr I, Althaus HH (2010) Mutual effects of caveolin and nerve growth factor signaling in pig oligodendrocytes. $\mathrm{J} \mathrm{Neu}$ rosci Res $\mathbf{8 8}, 572-588$.

[7] Schmitz M, Zerr I, Althaus HH (2011) Effect of cavtratin, a caveolin-1 scaffolding domain peptide, on oligodendroglial signaling cascades. Cell Mol Neurobiol 31, 991-997.

[8] Weiss E, Ramljak S, Asif AR, Ciesielczyk B, Schmitz M, Gawinecka J, Schulz-Schaeffer W, Behrens C, Zerr I (2010) Cellular prion protein overexpression disturbs cellular homeostasis in SH-SY5Y neuroblastoma cells but does not alter p53 expression: A proteomic study. Neuroscience 169, 1640-1650.

[9] Nieznanski K, Nieznanska H, Skowronek KJ, Osiecka KM, Stepkowski D (2005) Direct interaction between prion protein and tubulin. Biochem Biophys Res Commun 334, 403-411.

[10] Osiecka KM, Nieznanska H, Skowronek KJ, Karolczak J, Schneider G, Nieznanski K (2009) Prion protein region 23 32 interacts with tubulin and inhibits microtubule assembly. Proteins 77, 279-296.
[11] Hachiya NS, Watanabe K, Sakasegawa Y, Kaneko K (2004) Microtubules-associated intracellular localization of the NH2-terminal cellular prion protein fragment. Biochem Biophys Res Commun 313, 818-823.

[12] Nieznanski K, Podlubnaya ZA, Nieznanska H (2006) Prion protein inhibits microtubule assembly by inducing tubulin oligomerization. Biochem Biophys Res Commun 349, 391399.

[13] Martins VR, Brentani RR (2002) The biology of the cellular prion protein. Neurochem Int 41, 353-355.

[14] Weise J, Crome O, Sandau R, Schulz-Schaeffer W, Bähr M, Zerr I (2004) Upregulation of cellular prion protein $\left(\mathrm{PrP}^{\mathrm{C}}\right)$ after focal cerebral ischemia and influence of lesion severity. Neurosci Lett 372, 146-150.

[15] Weise J, Sandau R, Schwarting S, Crome O, Wrede A, SchulzSchaeffer W, Zerr I, Bähr M (2006) Deletion of cellular prion protein results in reduced Akt activation, enhanced postischemic caspase- 3 activiation, and exacerbation of ischemic brain injury. Stroke 37, 1296-1300.

[16] Schwarze-Eicke K, Keyvani K, Görtz N, Westaway D, Sachser N, Paulus W (2005) Prion protein $\left(\mathrm{PrP}^{\mathrm{C}}\right.$ ) promotes beta-amyloid plaque formation. Neurobiol Aging 26, 11771182.

[17] Takahashi RH, Tobiume M, Sato Y, Sata T, Gouras GK, Takahashi $\mathrm{H}$ (2011) Accumulation of cellular prion protein within dystrophic neurites of amyloid plaques in the Alzheimer's disease brain. Neuropathology 31, 208-214.

[18] Del Bo R, Scarlato M, Ghezzi S, Martinelli-Boneschi F, Fenoglio C, Galimberti G, Galbiati S, Virgilio R, Galimberti D, Ferrarese C, Scarpini E, Bresolin N, Comi GP (2006) Is M129V of PRNP gene associated with Alzheimer's disease? A case-control study and a meta-analysis. Neurobiol Aging 27, 770e1-770e5.

[19] Dermaut B, Croes EA, Rademakers R, Van den Broeck M, Cruts M, Hofman A, van Duijn CM, Van Broeckhoven C (2003) PRNP Val129 homozygosity increases risk for earlyonset Alzheimer's disease. Ann Neurol 53, 409-412.

[20] Riemenschneider M, Klopp N, Xiang W, Wagenpfeil S, Vollmert C, Müller U, Förstl H, Illig T, Kretschmar H, Kurz A (2004) Prion protein codon 129 polymorphism and risk of Alzheimer disease. Neurology 63, 364-366.

[21] Berr C, Helbecque N, Sazdovitch V, Mohr M, Amant C, Amouyel P, Alpérovitch A, Hauw JJ (2003) Polymorphism of the codon 129 of the prion protein (PrP) gene and neuropathology of cerebral ageing. Acta Neuropathol 106, 71-74.

[22] Laurén J, Gimbel DA, Nygaard HB, Gilbert JW, Strittmatter SM (2009) Cellular prion protein mediates impairment of synaptic plasticity by amyloid-beta oligomers. Nature 457, 1128-1132.

[23] Nygaard HB, Strittmatter SM (2009) Cellular prion protein mediates the toxicity of beta-amyloid oligomers: Implications for Alzheimer disease. Arch Neurol 66, 1325-1328.

[24] Gimbel DA, Nygaard HB, Coffey EE, Gunther EC, Laurén J, Gimbel ZA, Strittmatter SM (2010) Memory impairment in transgenic Alzheimer mice requires cellular prion protein. $J$ Neurosci 30, 6367-6374.

[25] Chung E, Ji Y, Sun Y, Kascsak RJ, Kascsak RB, Mehta PD, Strittmatter SM, Wisniewski T (2010) Anti-PrPC monoclonal antibody infusion as a novel treatment for cognitive deficits in an Alzheimer's disease model mouse. BMC Neurosci 11, 130.

[26] Caetano FA, Beraldo FH, Hajj GN, Guimaraes AL, Jürgensen S, Wasilewska-Sampaio AP, Hirata PH, Souza I, Machado CF, Wong DY, De Felice FG, Ferreira ST, Prado VF, Rylett RJ, Martins VR, Prado MA (2011) Amyloid-beta oligomers 
increase the localization of prion protein at the cell surface. $J$ Neurochem 117, 538-553.

[27] Balducci C, Beeg M, Stravalaci M, Bastone A, Sclip A, Biasini E, Tapella L, Colombo L, Manzoni C, Borsello T, Chiesa R, Gobbi M, Salmona M, Forloni G (2010) Synthetic amyloidbeta oligomers impair long-term memory independently of cellular prion protein. Proc Natl Acad Sci U S A 107, 22952300.

[28] Calella AM, Farinelli M, Nuvolone M, Mirante O, Moos R, Falsig J, Mansuy IM, Aguzzi A (2010) Prion protein and Abeta-related synaptic toxicity impairment. EMBO Mol Med 2, 306-314.

[29] Kessels HW, Nguyen LN, Nabavi S, Malinow R (2010) The prion protein as a receptor for amyloid-beta. Nature 466, E3E4.

[30] Han J, Zhang J, Yao H, Wang X, Li F, Chen L, Gao C, Gao J, Nie K, Zhou W, Dong X (2006) Study on interaction between microtubule associated protein tau and prion protein. Sci China C Life Sci 49, 473-479.

[31] Iliev AI, Ganesan S, Bunt G, Wouters FS (2006) Removal of pattern-breaking sequences in microtubule binding repeats produces instantaneous tau aggregation and toxicity. J Biol Chem 48, 37195-37204.

[32] Shaw G, Morse S, Ararat M, Graham FL (2002) Preferential transformation of human neuronal cells by human adenoviruses and the origin of HEK 293 cells. FASEB $J \mathbf{~ 1 6}$, 869-871.

[33] Bueler H, Fischer M, Lang Y, Bluethmann H, Lipp HP, DeArmond SJ, Prusnier SB, Aguet M, Weissmann C (1992) Normal development and behavior of mice lacking the neuronal cellsurface PrP protein. Nature 356, 577-582.

[34] Weidemann A, König G, Bunke D, Fischer P, Salbaum JM, Masters CL, Beyreuther K (1989) Identification, biogenesis, and localization of precursors of Alzheimer's disease A4 amyloid protein. Cell 57, 115-126.

[35] Hilbich C, Mönning U, Grund C, Masters CL, Beyreuther K (1993) Amyloid-like properties of peptides flanking the epitope of amyloid precursor protein specific monoclonal antibody 22C11. J Biol Chem 268, 26571-26577.

[36] Daebel V, Chinnathambi S, Biernat J, Schwalbe M, Habenstein B, Loquet A, Akoury E, Tepper K, Müller H, Baldus M, Griesinger C, Zweckstetter M, Mandelkow E, Vijayan V, Lange A (2012) $\beta$-Sheet core of tau paired helical filaments revealed by solid-state NMR. J Am Chem Soc 134, 13982-13989.

[37] Dassie E, Andrews MR, Bensadoun JC, Cacquevel M, Schneider BL, Aebischer P, Wouters FS, Richardson JC, Hussain I, Howlett DR, Spillantini MG, Fawcett JW (2013) Focal expression of adeno-associated viral-mutant tau induces widespread impairment in an APP mouse model. Neurobiol Aging 34, 1355-1368.

[38] Caillierez R, Bégard S, Lécolle K, Deramecourt V, Zommer N, Dujardin S, Loyens A, Dufour N, Aurégan G, Winderickx J, Hantraye P, Déglon N, Buée L, Colin M (2013) Lentiviral delivery of the human wild-type tau protein mediates a slow and progressive neurodegenerative tau pathology in the rat brain. Mol Ther 21, 1358-1368.

[39] Yoshida H, Terada S, Ishizu H, Ikeda K, Hayabara T, Ikeda K, Deguchi K, Touge T, Kitamoto T, Kuroda S (2010) An autopsy case of Creutzfeldt-Jakob disease with a V180I mutation of the PrP gene and Alzheimer-type pathology. Neuropathology 30, 159-164.

[40] Parkin ET, Watt NT, Hussain I, Eckman EA, Eckman CB, Manson JC, Baybutt HN, Turner AJ, Hooper NM (2007) Cellular prion protein regulates $\beta$-secretase cleavage of the
Alzheimer's amyloid precursor protein. Proc Natl Acad Sci U S A 104, 11062-11067.

[41] Cisse M, Mucke L (2009) Alzheimer's disease: A prion protein connection. Nature 457, 1090-1091.

[42] Hardy J, Allsop D (1991) Amyloid deposition as the central event in the aetiology of Alzheimer's disease. Trends Pharmacol Sci 12, 383-388.

[43] Griffiths HH, Whitehouse IJ, Baybutt H, Brown D, Kellett KA, Jackson CD, Turner AJ, Piccardo P, Manson JC, Hooper NM (2011) Prion protein interacts with BACE1 protein and differentially regulates its activity toward wild type and Swedish mutant amyloid precursor protein. J Biol Chem 286, 33489-33500.

[44] Yehiely F, Bamborough P, Da Costa M, Perry BJ, Thinakaran G, Cohen FE, Carlson GA, Prusiner SB (1997) Identification of candidate proteins binding to prion protein. Neurobiol Dis 3, 339-355.

[45] Hooper NM, Turner AJ (2008) A new take on prions: Preventing Alzheimer's disease. Trends Biochem Sci 33, 151-155.

[46] Cisse MA, Sunyach C, Lefranc-Jullien S, Postina R, Vincent B, Chacler F (2005) The disintegrin ADAM9 indirectly contributes to the physiological processing of cellular prion by modulating ADAM 10 activity. J Biol Chem 280, 4062440631.

[47] Vincent B, Sunyach C, Orzechowski HD, St George-Hyslop $\mathrm{P}$, Checler F (2009) p53-dependent transcriptional control of cellular prion by presenilins. J Neurosci $\mathbf{2 9}, \mathbf{6 7 5 2 - 6 7 6 0 .}$

[48] Kellett KA, Hooper NM (2009) Prion protein and Alzheimer disease. Prion 3, 190-194.

[49] Lee VMY, Giasson BI, Trojanowski JQ (2004) More than just two peas in a pod: Common amyloidogenic properties of tau and alphasynuclein in neurodegenerative diseases. Trends Neurosci 27, 129-134.

[50] Ghetti B, Tagliavini F, Giaccone G, Bugiani O, Frangione B, Farlow MR, Dlouhy SR (1994) Familial GerstmannSträussler-Scheinker disease with neurofibrillary tangles. $\mathrm{Mol}$ Neurobiol 8, 41-48.

[51] Ishizawa K, Komori T, Shimazu T, Yamamoto T, Kitamoto T, Shimazu K, Hirose T (2002) Hyperphosphorylated tau deposition parallels prion protein burden in a case of Gerstmann-Sträussler-Scheinker syndrome P102L mutation complicated with dementia. Acta Neuropathol 104, 342-350.

[52] Wang XF, Dong CF, Zhang J, Wan YZ, Li F, Huang YX, Han L, Shan B, Gao C, Han J, Dong XP (2008) Human tau protein forms complex with PrP and some GSS- and fCJD-related PrP mutants possess stronger binding activities with tau in vitro. Mol Cell Biochem 310, 49-55.

[53] Larson M, Sherman MA, Amar F, Nuvolone M, Schneider JA, Bennett DA, Aguzzi A, Lesné SE (2012) The complex $\operatorname{PrP}(\mathrm{c})$-Fyn couples human oligomeric $A \beta$ with pathological tau changes in Alzheimer's disease. J Neurosci 32, 1685716871.

[54] Hansson O, Zetterberg H, Buchhave P, Londos E, Blennow K, Minthon L (2006) Association between CSF biomarkers and incipient Alzheimer's disease in patients with mild cognitive impairment: A follow-up study. Lancet Neurol 5, 228-234.

[55] Evans DB, Rank KB, Bhattacharya K, Thomsen DR, Gurney ME, Sharma SK (2000) Tau phosphorylation at serine 396 and serine 404 by human recombinant tau protein kinase II inhibits tau's ability to promote microtubule assembly. J Biol Chem 275, 24977-24983.

[56] Wang GR, Shi S, Gao C, Zhang BY, Tian C, Dong CF, Zhou RM, Li XL, Chen C, Han J, Dong XP (2010) Changes of tau profiles in brains of the hamster infected with scrapie strains 
$263 \mathrm{~K}$ or 139 A possibly associated with the alteration of phosphate kinases. BMC Infect Dis 10, 86.

[57] Walz R, Amaral OB, Rockenbach IC, Roesler R, Izquierdo I, Cavalheiro EA, Martins VR, Brentani RR (1999) Increased sensitivity to seizures in mice lacking cellular prion protein. Epilepsia 40, 1679-1682.

[58] McLennan NF, Brennan PM, McNeill A, Davies I, Fotheringham A, Rennison KA, Ritchie D, Brannan F, Head MW, Ironside JW, Williams A, Bell JE (2004) Prion protein accumulation and neuroprotection in hypoxic brain damage. Am J Pathol 165, 227-235.
[59] Lee KJ, Panzera A, Rogawski D, Greene LE, Eisenberg E (2007) Cellular prion protein $\left(\mathrm{PrP}^{\mathrm{C}}\right)$ protects neuronal cells from the effect of huntingtin aggregation. J Cell Sci 120, 26632671.

[60] Klamt F, Dal-Pizzol F, Conte da Frota ML Jr, Walz R, Andrades ME, da Silva EG, Brentani RR, Izquierdo I, Fonseca Moreira JC (2001) Imbalance of antioxidant defense in mice lacking cellular prion protein. Free Radic Biol Med 30, 1137-1144. 